\title{
Actions of Crude Hydroalcoholic Extract of Pfaffia sp on Gastrointestinal Tract
}

\author{
Cristina Setim Freitas, Maria Fernanda Rodrigues de Paula, Lia Rieck and Maria \\ Consuelo Andrade Marques* \\ Departamento de Farmocologia; Setor de Ciências Biológicas; Universidade Federal do Paraná; Centro \\ Politécnico; C. P. 19031; Jardim das Américas; 81531-990; Curitiba - PR - Brazil
}

\begin{abstract}
The plants that compound the Pfaffia genus are used in folk medicine to treat gastric disturbances. This study examined the effects of a crude hydroalcoholic extract of Pfaffia sp on the gastrointestinal tract. Female Wistar rats

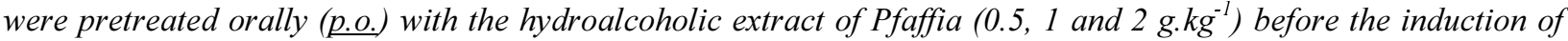
ulcer with hypothermic restraint stress (HRS), ethanol (ET) or indomethacin (IND). Control animals received water (C) or ranitidine $(60 \mathrm{mg} / \mathrm{kg})$ p.o. The hydroalcoholic extract of Pfaffia $\left(0.5,1\right.$ and $\left.2 \mathrm{mg}^{\mathrm{kg}} \mathrm{kg}^{-1}\right)$ protected rats against HRS and ET - induced ulcers, but was not able to protect the gastric mucosa against IND - induced ulcers. When injected into the duodenal lumen, the hydroalcoholic extract of Pfaffia inhibited basal and stimulated acid secretion in pylorus-ligated rats. These results indicate that this plant has a protective action against gastric lesions of the mucosa involving the reduction of gastric acid secretion.
\end{abstract}

Key words: Pfaffia, Amaranthaceae, ulcers, acid secretion

\section{INTRODUCTION}

Brazil is the most important center in harvesting of Pfaffia (Amaranthaceae) in America (Siqueira, 1988). This plant popularly known as "paratudo" ("for everething"), is used in folk medicine for scar and to treat gastric disturbances (Teske and Trentini, 1995). Pfaffia genus occurs in Guiana, Bolívia, Argentina and Brazil, mainly in states of São Paulo, Paraná, Mato Grosso and Goiás (Smith and Downs, 1972). After the discovery of pfaffic acid in Pfaffia paniculata Kuntze roots, have been grown the interest in the study of Pfaffia species due their antitumoural activity (Nishimoto et al, 1984). This study examined the effects of a crude hydroalcoholic extract of Pfaffia sp on

\footnotetext{
* Author for correspondence
}

gastrointestinal tract, seeking to validate the gastrointestinal effects of this plant.

\section{MATERIALS AND METHODS}

Animals: Adult female Wistar rats (180-250 g) were kept under controlled temperature $\left(20 \pm 2^{\circ} \mathrm{C}\right)$ and lighting (12:12h light/dark) conditions, with free access to water and food. When necessary animals were deprived from food $15-18 \mathrm{~h}$ before the experiments.

Plant material and preparation of extract: The hydroalcoholic extract of Pfaffia sp roots (EHP) was provided by FUNDAÇÃO HERBARIUM LABORATÓRIO BOTÂNICO 
LTDA, Colombo, Paraná, Brasil (lot no 112795 setember/1995 and lot $\mathrm{n}^{\circ} 062236$ - february/1997). It was obtained after 8 days maceration in percolator $(2.2 \mathrm{~kg}$ of Pfaffia sp dust in $70 \%$ alcohol - 10.0 1). The extract was filtered and the remainder was macerate $24 \mathrm{~h}$ with $70 \%$ alcohol and again filtered. The $\mathrm{pH}$ of the filtrate was adjusted to 7.67 with $\mathrm{KOH} 14 \%$. The aqueous extract was concentrated under vacuum to $1 / 4$ volume, lyophilized and stored under light protection and low temperature $\left(-5^{\circ} \mathrm{C}\right)$.

Antiulcer activity: Fasting rats were treated with the EHP (0.5, 1 and $2{\mathrm{~g} . \mathrm{kg}^{-1}}^{-1}$ per os - p.o.). After 1 $\mathrm{h}$ gastric lesions were induced by either stress (restraint for $3 \mathrm{~h}$ at $\left.4^{\circ} \mathrm{C}\right), 70 \%$ ethanol $(0.5 \mathrm{ml}$, p.o.) or indomethacin (20 mg. $\mathrm{kg}^{-1}$, subcutaneous s.c.). Animals were killed after either $3 \mathrm{~h}$ restraint stress at $4^{\circ} \mathrm{C}, 1 \mathrm{~h}$ ethanol administration or $6 \mathrm{~h}$ indomethacin injection. The stomach was dissected out, the mucosal side was gently washed to remove remaining food and examined under a stereoscope to determine the number of ulcer and to score the index of mucosal damage (IMD). Color, edema and hemorrhage in the gastric folds, as well pethechyae, ulcer numbers and ulcer sizes were taken into consideration to determine IMD index. Ranitidine treated animal were used for positive control (Senay and Levine, 1967; Robert et al, 1979; Djahanguiri, 1969).

Determination of gastric secretion and peptic activity: A pylorus ligature was carefully done in rats under ether anesthesia and the $\operatorname{EHP}(0.5,1$ and 2 g. $\mathrm{kg}^{-1}$ ) was injected into the duodenal lumen (i.d.). After $4 \mathrm{~h}$ the animals were killed and the gastric secretion was collected with a pipette. After washing the mucosal side of the stomach with $2 \mathrm{ml}$ of distilled water, gastric secretion volume and $\mathrm{pH}$ were determined. Total acidity of the gastric juice was titrated with $0.1 \mathrm{~N} \mathrm{NaOH}$ using phenolphthalein (2\%) as indicator. The EHP was also tested on gastric secretion induced in rats by bethanechol $\left(2.5 \mathrm{mg} \cdot \mathrm{kg}^{-1}\right.$, s.c. $)$ or histamine $(10$ mg. $\mathrm{kg}^{-1}$, s.c.) injected $1 \mathrm{~h}$ after surgery (Shay et al, 1945; Domer, 1971). Aliquots of $20 \mu \mathrm{l}$ of the gastric content were incubated with $500 \mu \mathrm{l}$ of albumin solution $\left(5 \mathrm{mg} \cdot \mathrm{mL}^{-1}\right.$ in $0.06 \mathrm{~N}$ hydrochloric acid) at $37{ }^{\circ} \mathrm{C}$ for 10 minutes. The reaction was stopped with $200 \mu \mathrm{l}$ of $10 \%$ trichloroacetic acid and the samples were centrifuged at $1500 \mathrm{~g}$ for 20 minutes. The supernatant was alkalinized with $2.5 \mathrm{~mL}$ of $0.55 \mathrm{M}$ sodium carbonate and $400 \mu \mathrm{l}$ of $1.0 \mathrm{~N}$ Folin's reagent was added to the tubes, which were incubated for 30 minutes at room temperature. The absorbance of the samples was determined by spectrophotometry at $660 \mathrm{~nm}$ and interject in a standard curve of tirosine for the determination of the concentration of pepsine in $\mu \mathrm{g} \operatorname{tirosin}^{-1}$ (Anson, 1938).

Statistics Analysis: Data were expressed as means \pm s.e.m. Statistical significance of the results was determined using a one-way-analysis of variance followed by the Tukey Kramer test. Results were considered different at a significance level of $\mathrm{P}<0.05$.

\section{RESULTS}

Gastric protection against stress, ethanol or indomethacin: Rats immobilized in the cold $\left(4{ }^{\circ} \mathrm{C}\right)$ for $3 \mathrm{~h}$ developed ulcers and other signs of gastric damage. The IMD index score was $7.71 \pm$ 1.57. Previous treatment with 0.5 or 2 g. $\mathrm{kg}^{-1} \mathrm{EHP}$ decreased the IMD to $3.80 \pm 0.49$ and $3.50 \pm 0.43$, respectively (Fig. $1-A$ ). Intragastric administration of $70 \%$ ethanol $(0.5 \mathrm{ml})$ produced in vehicle-treated rats an IMD of $23.3 \pm 5.03$ after 60 min. Pretreatment with 1 or $2{\mathrm{~g} . \mathrm{kg}^{-1}}^{\mathrm{E}} \mathrm{EHP}$ decreased the IMD to $8.83 \pm 2.82$ and $1.83 \pm 0.60$, respectively. (Fig. $1-B$ ). When control rats were treated with indomethacin $\left(20 \mathrm{mg} . \mathrm{kg}^{-1}\right.$, s.c. $)$, the gastric mucosa presented after $6 \mathrm{~h}$ IMD of $14.50 \pm$ 4.50. Pretreatment of the animals with the EHP was not able to alter the IMD.

Effect on gastric secretion and peptic activity: In control rats after $4 \mathrm{~h}$ of EHP inoculation, the volume of gastric juice secreted by control rats, over $4 \mathrm{~h}$, was $9.2 \pm 0.6 \mathrm{ml}$ with a $\mathrm{pH} 1.8 \pm 0.05$, total acidity of $0.031 \pm 0.003 \mathrm{mEq}\left[\mathrm{H}^{+}\right] \cdot \mathrm{mL}^{-1}$ and peptic activity of $127.0 \pm 4.2 \mu \mathrm{g}$ tirosin. $\mathrm{ml}^{-1}$. The EHP administration decreased the gastric juice volume to $5.9 \pm 0.4$ and $4.8 \pm 0.4 \mathrm{ml}$, the total acidity to $0.016 \pm 0.003$ and $0.004 \pm 0.001$ $\mathrm{mEq}\left[\mathrm{H}^{+}\right] \cdot \mathrm{mL}^{-1}$ and increased the $\mathrm{pH}$ to $2.8 \pm 0.4$ and $3.7 \pm 0.3$. The peptic activity was reduced with all the doses tested $(111.0 \pm 5.4,104.0 \pm 3.3$ and $87.0 \pm 6.0 \mu \mathrm{g}$ tirosin. $\mathrm{ml}^{-1}$ ) (Fig. 2). Injection of bethanechol $\left(2.5 \mathrm{mg} . \mathrm{kg}^{-1}\right.$, s.c. $)$ increased the 
volume of basal acid secretion volume in pylorusligated rats from $7.1 \pm 0.3$ to $12 \pm 0.9 \mathrm{ml}$, the total acidity from $0.029 \pm 0.005$ to $0.063 \pm 0.006$ $\mathrm{mEq}\left[\mathrm{H}^{+}\right] \cdot \mathrm{mL}^{-1}$ and reduced the $\mathrm{pH}$ from $1.8 \pm 0.04$ to $1.4 \pm 0.05$. The peptic activity was not altered. Pretreatment with $0.5,1$ or $2 \mathrm{~g} \cdot \mathrm{kg}^{-1}$ EHP inhibited gastric juice volume induced by bethanechol to 8.3 $\pm 0.6,8.7 \pm 0.4$ and $6.2 \pm 0.8 \mathrm{ml}$, respectively. It pretreatment also inhibited the total acidity of stomach secretion induced by bethanechol to 0.042 $\pm 0.003,0.04 \pm 0.005$ and $0.019 \pm 0.003$ $\mathrm{mEq}\left[\mathrm{H}^{+}\right] \cdot \mathrm{mL}^{-1}$. The $\mathrm{pH}$ was increased to $2.0 \pm$ 0.08 , when $2.0{\mathrm{~g} . \mathrm{kg}^{-1}}^{-1}$ bethanecol was used (Fig. 3).
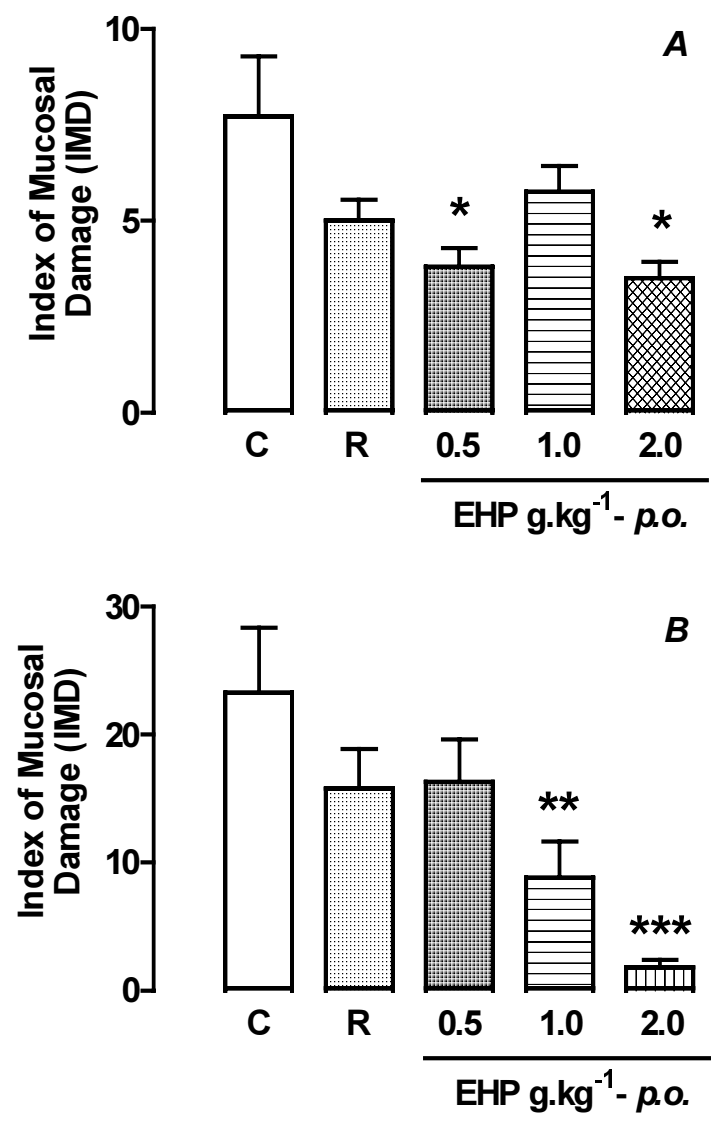

Figure 1 - Protective effect of the hydroalcoholic extract of Pfaffia - EHP- (C: control water, 0.5 ml. $100 \mathrm{~g}^{-1}$; R: ranitidine, 60 mg. $\mathrm{kg}^{-1}$ - p.o.) against gastric lesions induced by hypothermic restraint stress $(A)$ and $70 \%$ ethanol $(B)$. The data are means \pm s.e.m., $\mathrm{n}=6$ in all groups. $*$ different from the control group at $\mathrm{p}<0.05, * * \mathrm{p}<0.01$ and $* * * \mathrm{p}<0.001$.
Similarly, injection of histamine $\left(10 \mathrm{mg} \cdot \mathrm{kg}^{-1}\right.$, s.c. $)$ increased the volume of basal acid secretion in pylorus-ligated rats from $6.5 \pm 0.5$ to $9.1 \pm 0.8$ $\mathrm{ml}$, the total acidity from $0.03 \pm 0.007$ to $0.05 \pm$ $0.007 \mathrm{mEq}\left[\mathrm{H}^{+}\right] \cdot \mathrm{mL}^{-1}$. Pretreatment with $2.0 \mathrm{~g} \cdot \mathrm{kg}^{-1}$ of EHP prevented this effect, reducing the volume of gastric juice volume to $4.3 \pm 0.2 \mathrm{ml}$ and the total acidity to $0.007 \pm 0.001 \mathrm{mEq}\left[\mathrm{H}^{+}\right] \cdot \mathrm{mL}^{-1}$. The $\mathrm{pH}$ was increased to $2.5 \pm 0.1$ (Fig. 4).

\section{DISCUSSION}

In the present study, the hydroalcoholic extract of Pfaffia sp was tested to verify its action on the gastrointestinal tract reported in folk medicine. The results indicated that the extract (EHP) protected against gastric mucosal damage induced by ethanol, indicating an important cytoprotective action against the direct necrosing action of ethanol. Ethanol can cause injury to the gastric mucosa by damaging and breaking the gelatinous layer composed of mucus and bicarbonate that protects the stomach (Szabo, 1991; Glavin et al, 1992).

The EHP also protected against hypothermic restraint stress-induced ulcers (HRS), suggesting that active principles extract with ethanol from Pfaffia sp can oppose the increase in parasympathetic tonus promoted by HRS, with consequent stimulation of type $\mathrm{M}_{3}$ muscarinic receptors of parietal cells, increased levels of gastrin regulator peptide (Glavin et al, 1991; Pachaly et al, 1993). 

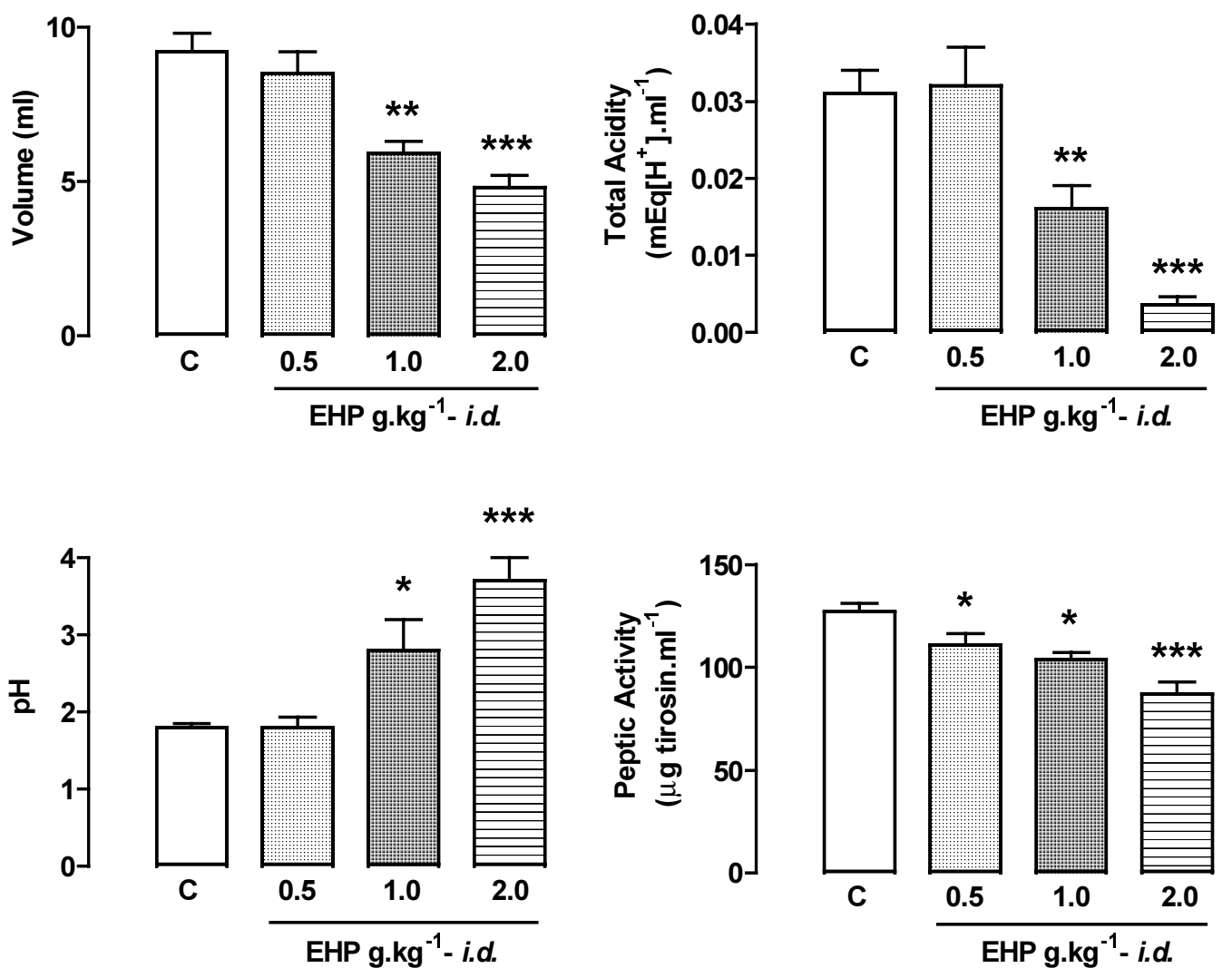

Figure 2 - Effects of the hydroalcoholic extract of Pfaffia - EHP - (C: control water, $\left.0.5 \mathrm{ml} .100 \mathrm{~g}^{-1}\right)$ on the volume, total acidity, $\mathrm{pH}$ and peptic activity of basal gastric acid secretion after 4 hours of pylorus ligature in female rats. The data are means \pm s.e.m., $\mathrm{n}=6$ in all groups. * different from the control group at $\mathrm{p}<0.05, * * \mathrm{p}<0.01$ and $* * * \mathrm{p}$ $<0.001$.

The EHP also can oppose to the histamine release stimulation by enterochromaffin cells and reduction of gastric mucosa blood flow also promoted by HRS (Hersey and Sachs, 1995; Brodie et al, 1962). The treatment with EHP can modify all of them factors that promote increase of gastric secretion and reduction of protective factors, with consequent protection against necrosis, hemorrhage, erosions and ulcers in the gastric mucosa. The EHP also reduced basal gastric acid and bethanechol- or histamineinduced secretion. These effects could not be attributed to a topic effect on the gastric mucosa since the extract was always injected in the duodenal lumen. On the other hand, a specific blockade of different receptors of the physiological secretagogues is unexpected. Taking into account that muscarinic agonists and gastrin may stimulate histamine release to induce acid secretion in vivo (Schubert, 1997), future studies should be done to test whether the extract of Paffia sp inhibits the histaminergic pathway of acid secretion in vitro, considering either the $\mathrm{H}_{2}$ receptors, cAMP production or the proton pump. These studies may be done with a specie of Paffia with known origin and correct botanical nomenclature.

In conclusion, the hydroalcoholic extract obtained from Pfaffia sp roots effectively protected the gastric mucosa and inhibited gastric acid secretion in rats. These results confirmed folk information regarding the use of the plant in gastric upset. 

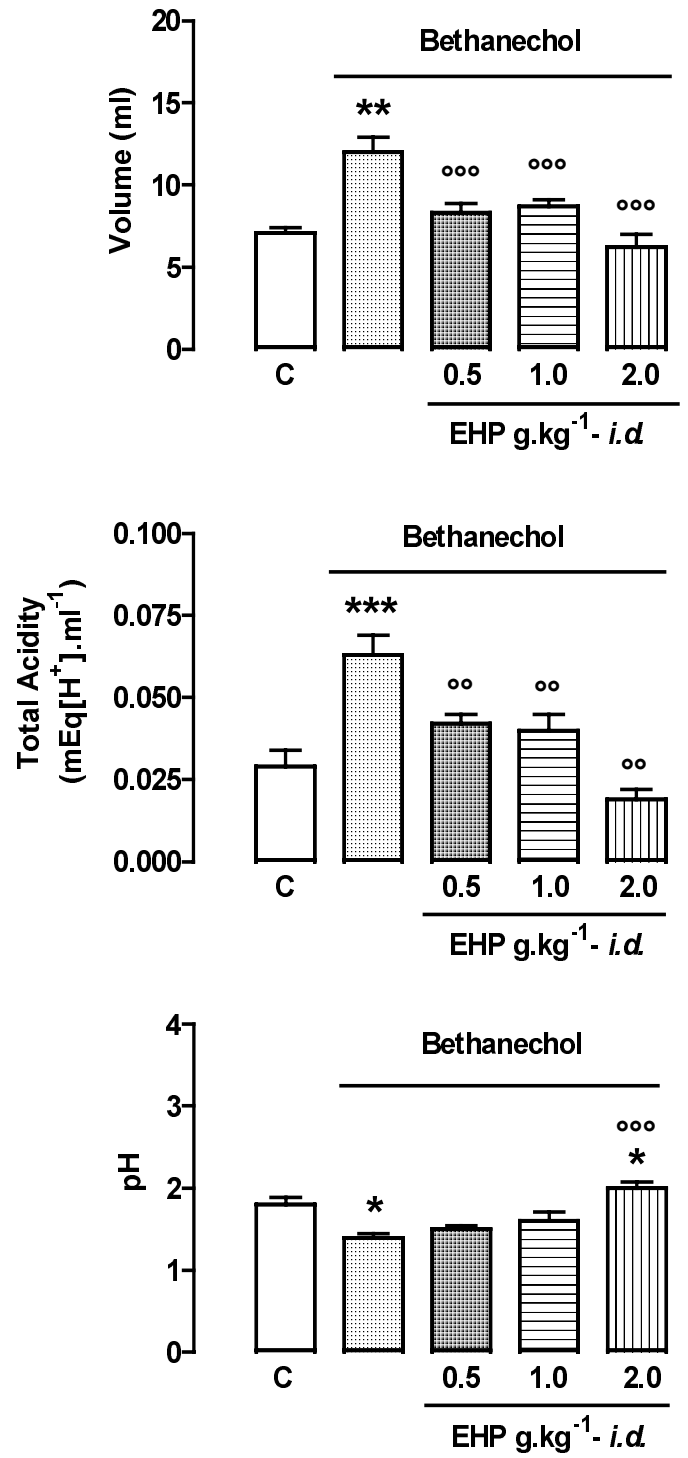

Figure 3 - Effects of the hydroalcoholic extract of Pfaffia - EHP - (C: control water, $\left.0.5 \mathrm{ml} .100 \mathrm{~g}^{-1}\right)$ on the volume, total acidity and $\mathrm{pH}$ of gastric acid secretion induced by bethanechol ( $2.5 \mathrm{mg} . \mathrm{kg}^{-1}$, s.c. $)$, collected after 4 hours of pylorus ligature in female rats. The data are means \pm s.e.m., $\mathrm{n}=6$ in all groups. * different from the control group at $\mathrm{p}<0.05, * * \mathrm{p}<0.01$ and $* * * \mathrm{p}<$ $0.001 ;{ }^{\circ}$ different of bethanechol group at $\mathrm{p}<0.01$ and ${ }_{\circ \circ} \mathrm{p}<0.001$.
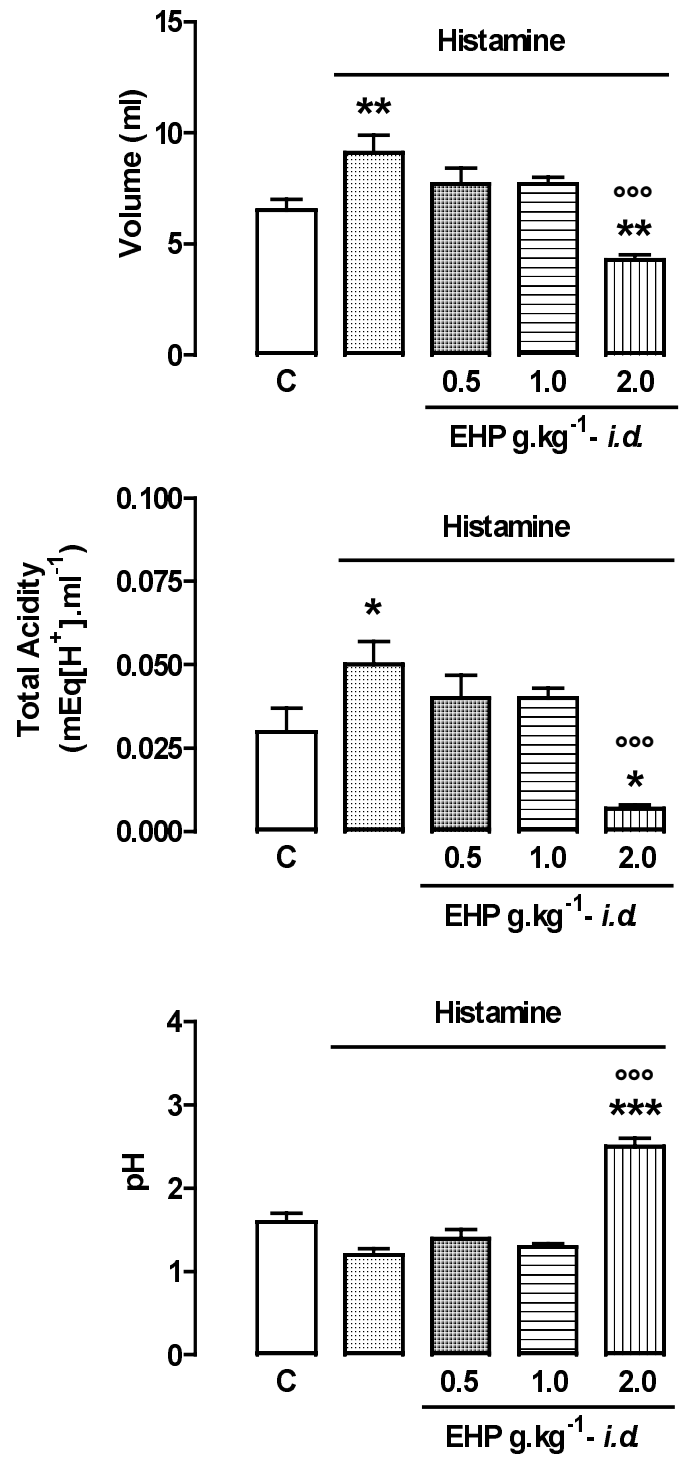

Figure 4 - Effects of the hydroalcoholic extract of Pfaffia - EHP - (C: control water, $0.5 \mathrm{ml} .100 \mathrm{~g}^{-1}$ ) on the volume, total acidity and $\mathrm{pH}$ of gastric acid secretion induced by histamine (10 mg. $\mathrm{kg}^{-1}$, s.c.), collected after 4 hours of pylorus ligature in female rats. The data are means \pm s.e.m., $n=6$ in all groups. * different from the control group at $\mathrm{p}<0.05, * * \mathrm{p}<0.01$ and $* * * \mathrm{p}<$ $0.001 ;{ }^{\circ \circ}$ different of histamine group at $\mathrm{p}<0.001$.

\section{RESUMO}

As plantas que compõem o gênero Pfaffia são utilizadas na medicina popular para tratar distúrbios gástricos. O presente estudo verificou os efeitos de um extrato bruto hidroalcoólico de Pfaffia sp sobre o trato gastrointestinal. Ratos Wistar fêmeas, foram pré-tratados por via oral 
(p.o.) com o extrato hidroalcoólico de Pfaffia sp $(0,5 ; 1,0$ e $2,0 \mathrm{~g} / \mathrm{kg}) 1$ hora antes da indução de úlceras com estresse por imobilização e frio, com etanol $70 \%$ ou indometacina.

Animais controle receberam água $(\mathrm{C})$ ou ranitidina (R: $60 \mathrm{mg} / \mathrm{kg}$ ) - p.o. $\mathrm{O}$ tratamento com o extrato protegeu a mucosa gástrica contra o aparecimento de úlceras induzidas por estresse e etanol, mas não foi capaz de proteger a mucosa contra úlceras induzidas por indometacina. Quando injetado pela via intraduodenal (na luz do duodeno - i.d.), o extrato hidroalcoólico de Pfaffia sp inibiu tanto a secreção ácida gástrica basal quanto a estimulada com histamina e betanecol (drogas agonistas), em ratas com ligadura de piloro. Os resultados obtidos neste trabalho indicam que esta planta apresenta ação protetora da mucosa gástrica, envolvendo a redução da secreção gástrica.

\section{REFERENCES}

Anson, M. L. (1938), The estimation of pepsin, trypsin, papain and catepsin with hemoglobin. J. Gener. Physiol., 22, 78-89.

Brodie, D.; Marshall, R. W. and Moreno, O. M. (1962), Effect of restrain on gastric acidity in rat. Am. J. Physiol., 202, 812-814.

Djahanguiri, B. (1969), The production of acute gastric ulceration by indomethacin in the rat. Scand. J. Gastroenterol., 4, 265.

Domer, F. R. (1971), Animal experiments in pharmacological analysis. Charles C. Thomas Publisher, 669.

Glavin, G. B.; Murison, R.; Overmier, J. B.; Pare, W. P.; Bakke, H. K.; Henke, P. G. and Hernandez, D. E. (1992), The neurobiology of stress ulcers. Brain Research, 16, 301-343.

Glavin, G. B.; Gary, B.; Sansor, S. (1992), Experimental gastric mucosal injury: laboratory models reveal mechanisms of pathogenics and new therapeutic strategies. Faseb J., 6, 825-831.

Hersey, S. J. and Sachs, G. (1995), Gastric acid secretion. Physiological Rev. USA, 75, 155-189.

Nishimoto, N.; Nakai, S.; takagi, N.; Hayashi, S.; Takemoto, T.; Odashima, S.; Kizu, H. and Wada, Y. (1984), Pfaffosides and nortriterpenoids saponins from Pfaffia paniculata. Phytochemistry, 23, 139-142.

Pachaly, J. R.; Werner, P. R.; Schimanski, J. C. and Ciffoni, E. M. G. (1993), Estresse por captura e contensão em animais selvagens. A Hora Veterinária, 74, 47-52.
Robert, A.; Nezamis, J. E.; Lancaster, C. and Hauchar, A. J. (1979), Cytoprotection by prostaglandins in rats. Prevention of gastric necrosis produced by alcohol, $\mathrm{HCl}, \mathrm{NaOH}$, hypertonic $\mathrm{NaCl}$ and thermal injury. Gastroenterology, 77, 433-443.

Schubert, M. L. (1997), Regulation of gastric secretion. Curr. Opinion Gatroenterol., 13, 441-450.

Senay, S. E. and Levine, R. J. (1967), Synergism between cold and restraint for rapid production of stress ulcer in rats. Proc. Soc. Exp. Biol. Med., 124, 1221-1223.

Shay, H.; Komarov, S. A.; Fels, S. E.; Meraze, D.; Gruenstein, M. and Siplet, H. (1945), A simple method for the iniform production of gastric ulceration in rat. Gastroenterology, 5, 43-61.

Siqueira, J.C. (1988), Considerações taxonômicas sobre as espécies brasileiras do gênero Pfaffia (Amaranthaceae) Acta Biológica Leopoldensia, 10, 269-278.

Smith, L. B. and Downs, R. J. (1972), Amarantáceas. Flora Ilustrada Catarinense, Parte I, Fascículo: As plantas amara. pp. 40-42.

Szabo, S. (1991), Mechanisms of gastric mucosal injury and protection. J. Clin. Gastroenterol., 13, 21S-34S.

Teske, M. and Trentini, A. M. M. M. (1995), Herbarium. Compêndio de Fitoterapia, Fundação Herbarium Laboratório Botânico LTDA, Curitiba, Paraná. 137 pp.
Received: December 04, 2001; Revised: July 24, 2002; Accepted: January 17, 2002. 